\title{
Android Subcutaneous Adipose Tissue Topography in Females with Polycystic Ovary Syndrome: A Visible Phenotype Even in Juveniles
}

\author{
Moeller Reinhard, Giuliani Albrecht, Mangge Harald, Tafeit Erwin, \\ Glaeser Margit, Schrabmair Walter and Horejsi Renate \\ Medical University Graz \\ Austria
}

\section{Introduction}

Polycystic Ovary-Syndrome (PCOS) is a complex endocrine disorder which affects approximately $5-10 \%$ of females of reproductive age (Asunción et al, 2000, DiamantiKandarakis et al, 1999, Dunaif A, 1997). The syndrome is characterized by abnormal menstrual cyclicity, ovulatory dysfunction, hyperandrogenism and hirsutism (Goodarzi et al, 2011, Hatch et al, 1981). Functional ovarian hyperandrogenism is due to hyperinsulinemia, insulin resistance and hyperlipidemia. The acute problems of the patient, namely ovarian abnormalities and ovulation induction for subfertility, have shifted toward the prevention of long-term health consequences (Cupisti et al, 2007). Insulin resistance is a key feature of females with PCOS, especially, when they are overweight or obese. This has important effects in favouring androgen excess and oligo-anovulation. It is evident, that females with PCOS, especially the overweight ones, have a higher risk for developing type 2 diabetes. It is suggested, that insulin resistance is even more common in overweight patients with PCOS that in lean females. There is a continuum of decrease in insulin sensitivity with increasing abdominal fat accumulation (Zelzer et al, 2011). Hyperandrogenism is associated with fat accumulation at the body trunk. This android, "apple"-like fat pattern is a risk for metabolic disturbances like cardiovascular diseases and type 2 diabetes (Cupisti et al, 2007, Nathan \& Moran, 2008).

Early symptoms of PCOS such as growing precociously pubic hair, height growth and overweight, do already appear during childhood and adolescence, but the problems are not diagnosed seriously (Bronstein et al, 2011, Oliveira et al, 2010). Obesity in childhood is widely spread worldwide. Lower physical activity and a general availability of high caloric food may cause high proportions of overweight and obese juveniles for higher risks for females to develop PCOS.

Females with PCOS need medical care for different reasons: the pediatrician may be contacted because of childhood obesity or abnormal menstrual bleeding. The dermatologist may be approached for hirsutism. The gynecologist may be consulted for menstrual cycle 
abnormalities, unfulfilled wish for pregnancy, or complications during pregnancy. The physician of internal medicine may be consulted for obesity or type 2 diabetes. The cause of a first contact of the patient with a physician is often a rapid weight gain. The consulted physician will measure BMI or waist circumference. The suggestion of metabolic terms, however, should focus the interest on the distribution of body fat, not only on body weight. A rapid, non-invasive and precise measurement of the thickness of adipose tissue might render important information of metabolic risks even in juveniles and in young females. Advanced statistic methods could support the detection of a PCOS - like fat distribution and confirm the risk for metabolic disturbances (Tafeit et al, 2000; Tafeit et al, 2000a, Tafeit et al, 1999).

\section{The lipometer}

Measuring body fat has increasing priority in medical care, but also in sports and human biology. The standard methods are caliper, computed tomography, underwater weighing, nuclear magnetic resonance, bio-impedance or dual energy X-ray absoptiometry (DEXA). These methods have several disadvantages like high costs, stress for the subject, radiological burden or lack of precision.

The newly certificated optical device Lipometer is a computerized optical system for precise measurement of the absolute thicknesses of subcutaneous adipose tissue in mm (Tafeit et al, 2000b).

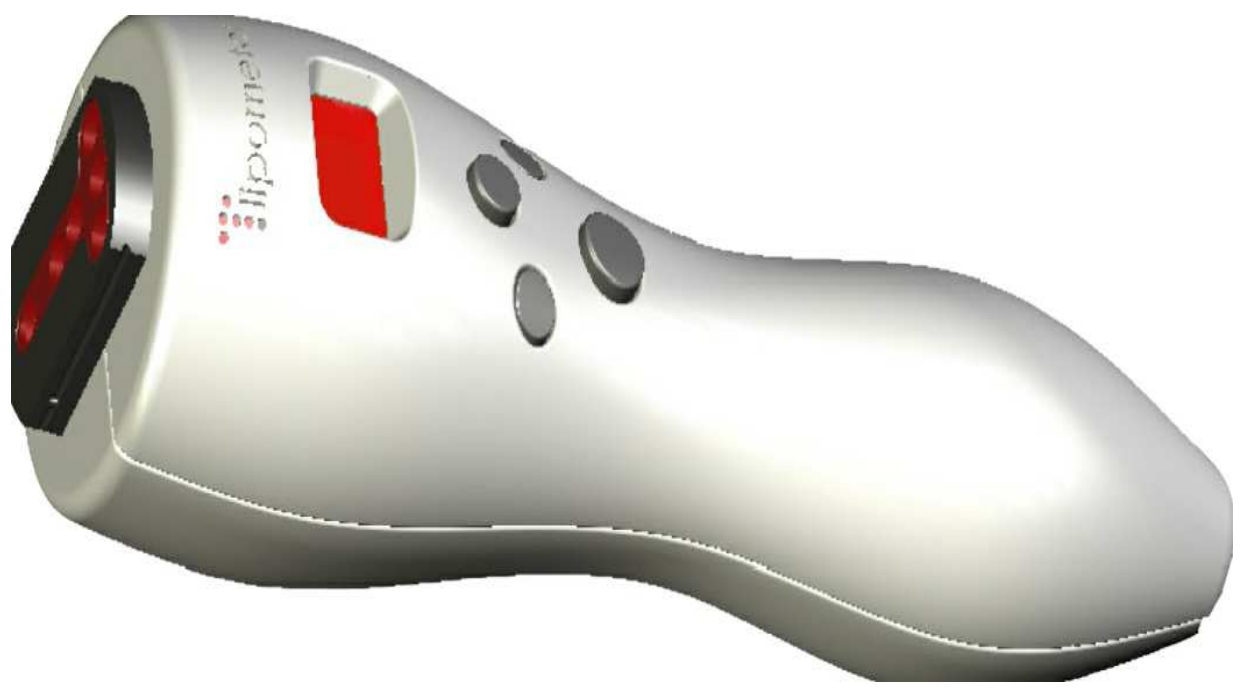

Fig. 1. The Lipometer, an optical device to measure the thickness of subcutaneous adipose tissue layers

\subsection{Design of the lipometer}

The sensor head of the Lipometer consists of five light-emitting diodes as light sources (wavelength $660 \mathrm{~nm}$, light intensity $3000 \mathrm{mcd}$ ) and a photodetector. The diodes illuminate 
the body site to be measured, forming geometrical patterns that vary in succession. The light intensities from the adipose tissue are back-scattered, amplified, digitized and render fat thickness of the named body site in $\mathrm{mm}$ (Moeller at al, 2000). Calibration and evaluation was done by computed tomography as reference method.

\subsection{Procedere of measuring Subcutaneous Adipose Tissue Topography (SAT-Top)}

Fifteen anatomically well defined body sites from 1-neck to 15-calf give the information of individual body fat distribution (Subcutaneous adipose tissue topography, SAT-Top) (Tafeit et al, 2007). The coefficient of variation of these 15 body sites was published previously (Sudi et al, 2000).
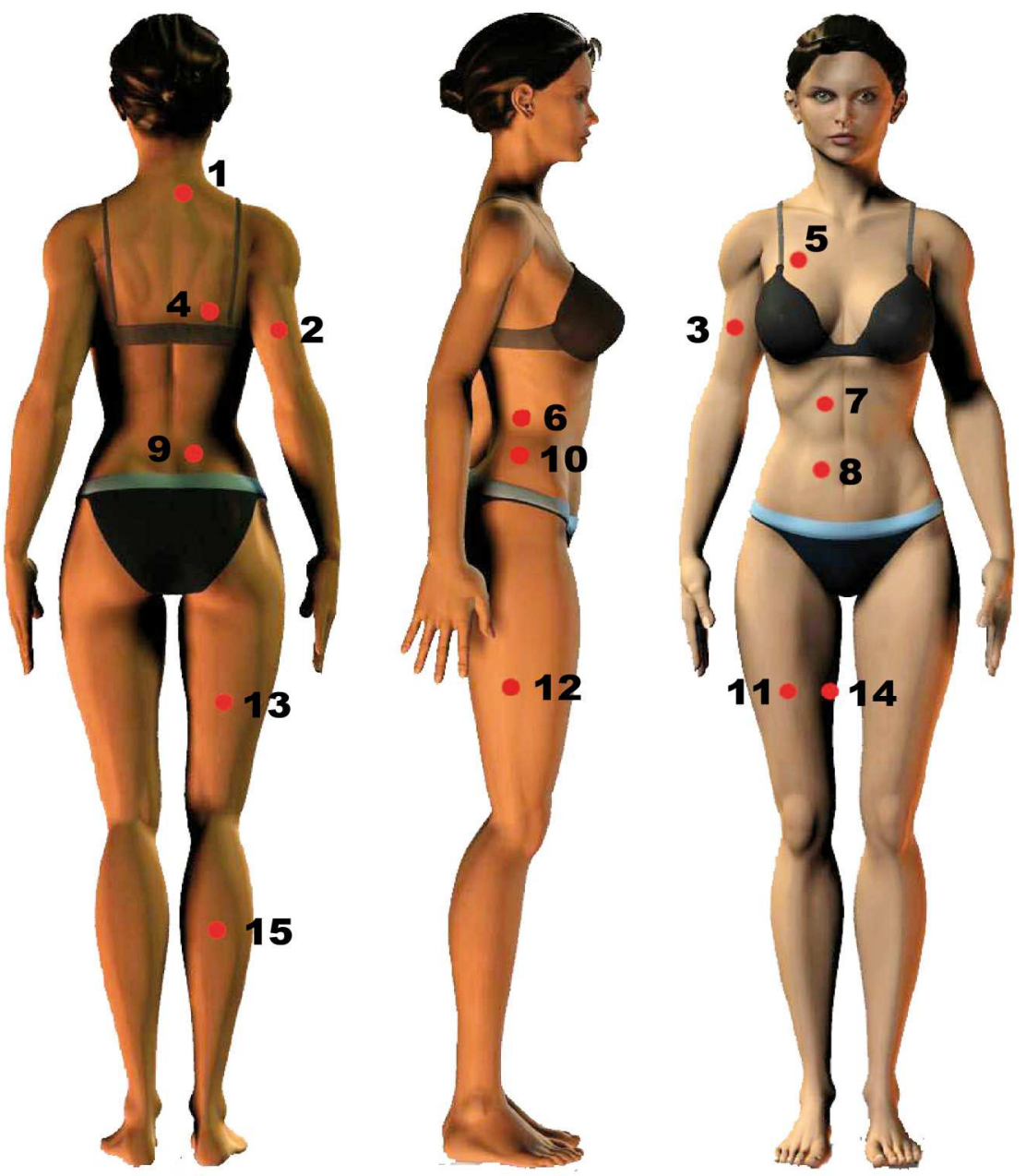

Fig. 2. The set of fifteen anatomically well- defined body sites from 1-neck to 15-calf on the right side oft the human body 

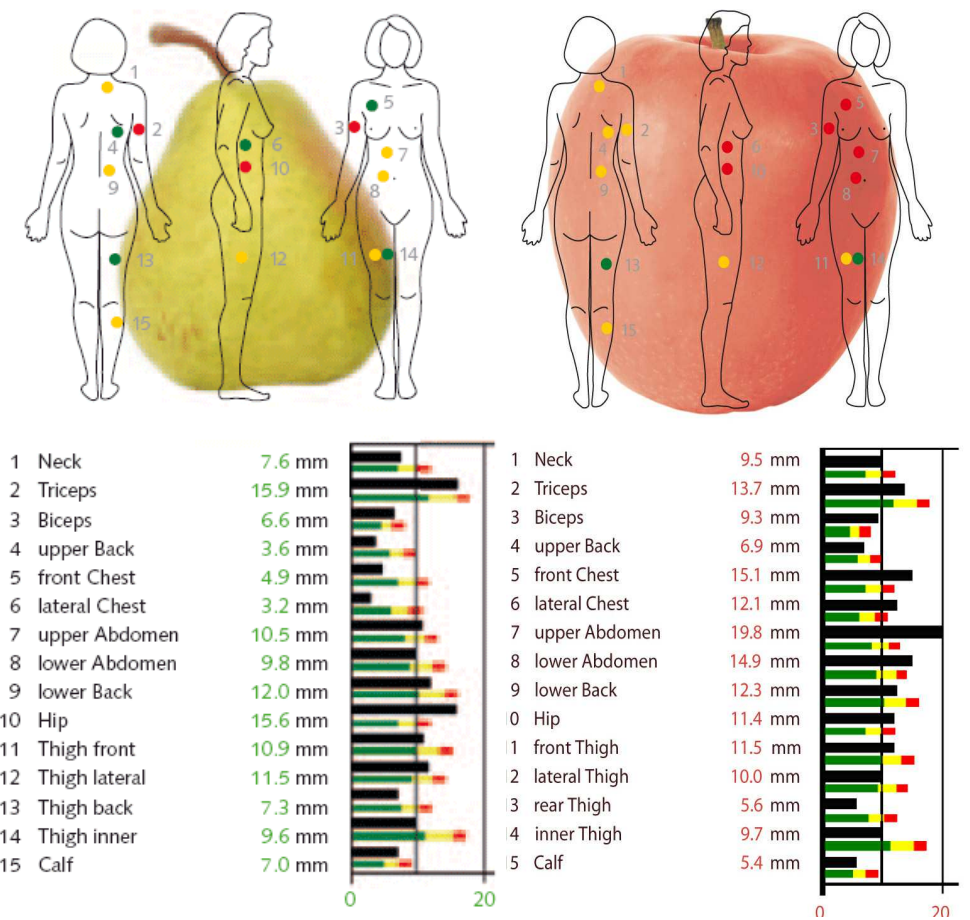

Fig. 3. SAT-Top protocols: Female pear profile (left) and female apple profile (right) with the same age, weight and BMI

SAT-Top of the measured person is like an individual "fingerprint", defined by genetics, sex, nutritional status, hormonal and metabolic disorders and modified by age and life style.

\subsection{Comparing an individually measured SAT-Top with the data of healthy or diseased subjects of the same sex and age}

SAT-Tops of more than 3000 men, women and children are included in the Lipometer data base, healthy subjects as well as patients with type 2 diabetes, coronary heart disease, obesity and fertility disorders (Moeller et al, 2000a).

Both, male and female children develop about the same SAT-Top between birth and the age before the onset of puberty. At the age of about eleven years the adipose tissue layers on the extremities increase in girls. The maximum of the adipose tissue layers on the legs is reached at the age of 22 years. Boys, however, decrease the thicknesses of the subcutaneous adipose tissue layers at the extremities. The minimum of the thickness of adipose tissue layers at the extremities is reached at the age of 17 years.

At the age of 20 years men and women increase adipose tissue layers at their trunks until they are about 60 years old. Men have skinny extremities, women have not.

In later life man and women stop increasing the thicknesses of adipose tissue layers at the trunks and turn back to thinner layers at their trunks. 
Patients with obesity, type 2 diabetes, coronary heart disease, PCOS and anorexia nervosa have significantly different SAT-Tops compared to age-matched healthy controls. Anorectic patients have not the typical patterns of a male or female body fat distribution, but all over the body extremely thin adipose tissue layers of somewhat less than one mm. Overweight patients increase adipose tissue layers on neck, trunk, abdomen, hip and back and accumulate visceral fat, the "apple"-like body fat distribution. An even more pronounced "super- apple"- like body silhouette can also be found in overweight PCOS women and patients with type 2 diabetes and coronary heart disease (Moeller et al, 2000).

\section{Polycystic Ovary Syndrome and body fat distribution}

The diagnosis of PCOS is based on the Rotterdam criteria (The Rotterdam ESHRE-ASRMSponsored consensus workshop group, 2004). Two out of three of the following are required for the diagnosis: oligo- and/or anovulation, clinical and/or biochemical signs of hyperandrogenism, polycystic ovaries by ultrasound. Disorders with a similar clinical presentation have to be excluded.

About half of the females with PCOS are overweight or obese. The body fat distribution and SAT-Top is a better indicator of metabolic changes than waist circumference or BMI. Hyperandrogenism can be attributed to a fat accumulation at the trunk (Enea et al, 2011). Females with an android body silhouette have a higher risk for developing cardiovascular diseases, or type 2 diabetes (Goodarzi et al, 2011).

\subsection{SAT-Top comparison of adult females}

SAT-Top was measured in healthy females, overweight and lean females with PCOS. Diagnosis was performed by the Division of Reproductive Endocrinology of the Medical University Graz because of unfulfilled wish of pregnancy. Polycystic ovaries were diagnosed by ultrasound. Oligo- and anovulation, acne or alopecia and /or elevated androgen levels were identified (Hatch et al, 1981).

\begin{tabular}{|c|c|c|c|}
\hline & $\begin{array}{l}\text { healthy } \\
\text { controls }\end{array}$ & obese PCOS & lean PCOS \\
\hline $\mathrm{N}$ & 87 & 18 & 15 \\
\hline Age (years) & $28,1+4,1$ & $27,3+4,9$ & $25,6+4,1$ \\
\hline Height $(\mathrm{cm})$ & $165,5 \pm 6,6$ & $164,5 \pm 6,5$ & $165,8 \pm 8,3$ \\
\hline Weight $(\mathrm{kg})$ & $60 \pm 9,4$ & $83,9 \pm 13,6$ & $56,8+7,6$ \\
\hline BMI $\left(\mathrm{kg} / \mathrm{m}^{2}\right)$ & $21,9+2,9$ & $31,0+4,7$ & $20,7+2,3$ \\
\hline
\end{tabular}

Table 1. Personal data of adult females

The green area in figure 4 shows the body fat distribution of healthy females, a typical "pear"like body fat distribution with thicker adipose tissue layers at the extremities: triceps and legs.

Lean young females with PCOS (orange bars in figure 4) have thinner adipose tissue layers over the whole body and relatively thin layers at the extremities, but the profile is still more "pear"-like. 
Overweight and obese females with PCOS (red bars in the figure) have a remarkable different body fat distribution with significantly thicker fat layers at all body sites from neck to hip and thinner layers at their legs, a typical "apple" - like body fat distribution (Tafeit et al, 2003).

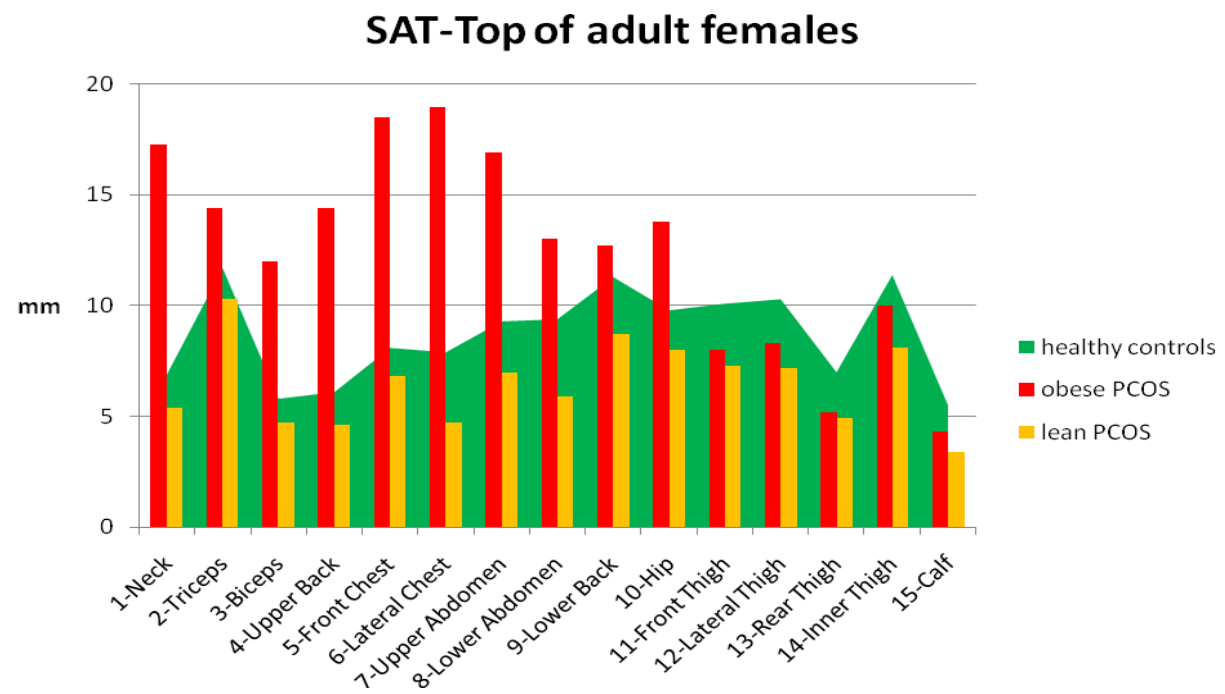

Fig. 4. SAT-Tops of healthy control females (green area), obese women with PCOS (red bars) and lean women with PCOS (orange bars)

\subsection{Body fat distribution of women with type 2 diabetes}

SAT-Top of 20 women with type 2 diabetes was published previously and the subcutaneous body fat pattern has strong similarities to obese women with PCOS.

The personal data are shown in table 2:

\begin{tabular}{|l|c|c|}
\hline & healthy women & type 2 diabetes \\
\hline $\mathrm{N}$ & 122 & 20 \\
\hline Age (years) & $58,1 \pm 6,2$ & $62,4 \pm 6,6$ \\
\hline Height $(\mathrm{cm})$ & $161,9 \pm \underline{5}, 9$ & $160,9 \pm 5,4$ \\
\hline Weight $(\mathrm{kg})$ & $72,1 \pm 11,6$ & $75,4 \pm 13,1$ \\
\hline BMI $\left(\mathrm{kg} / \mathrm{m}^{2}\right)$ & $27,5 \underline{+4}, 5$ & $29,1 \pm 4,9$ \\
\hline
\end{tabular}

Table 2. Personal data of elderly females

Figure 5 shows SAT-Tops of healthy controls (green area) compared to those with type 2 diabetes (violet bars):

The healthy elderly controls have increased thicknesses of adipose tissue layers located at the trunk during the postmenopausal aging processes. Overthere females with type 2 diabetes develop thicker fat layers at their trunks, while the extremities are thinner than that of healthy elderly controls (Tafeit et al, 2000). 


\section{SAT-Top of elderly females}

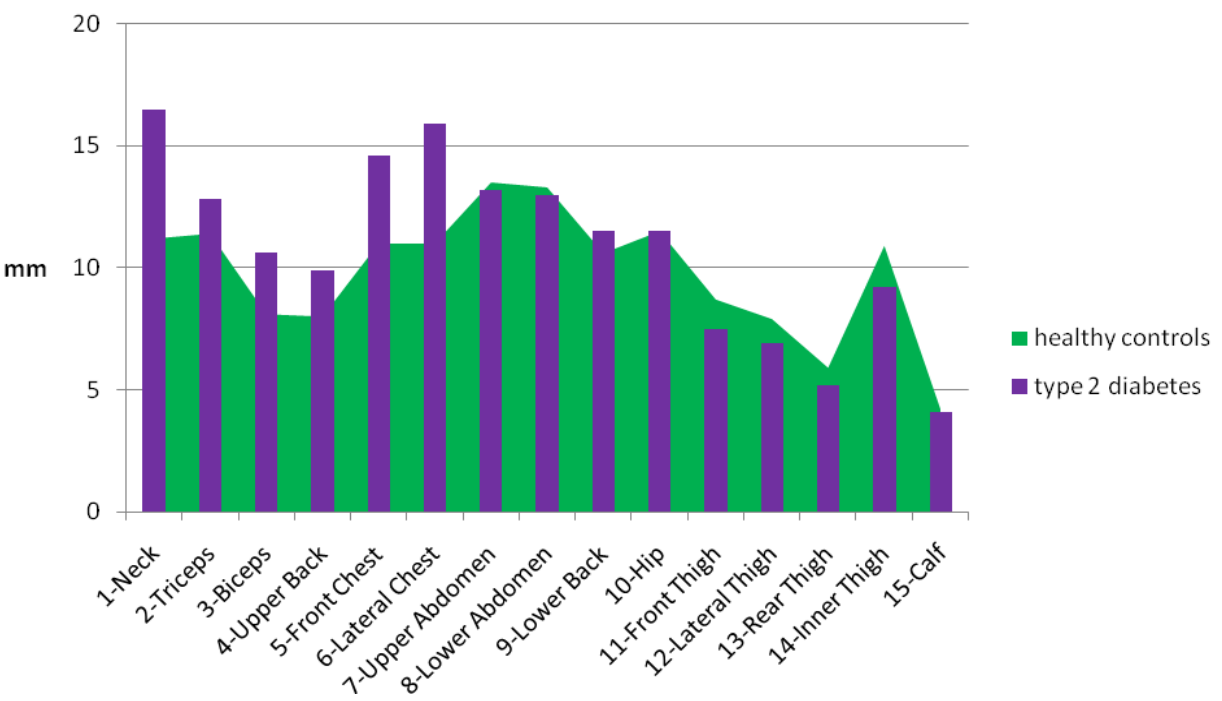

Fig. 5. SAT-Tops of healthy elderly controls (green area) and elderly females with type 2 diabetes (violet bars).

\subsection{Body fat distribution of normal weight and overweight young girls}

SAT-Top was measured in 25 overweight, female juveniles and age-matched controls.

The table shows the personal data:

\begin{tabular}{|c|c|c|}
\hline & healthy controls & overweight girls \\
\hline $\mathrm{N}$ & 301 & 25 \\
\hline Age (years) & $12,6 \pm 1,3$ & $13,1 \pm 0,3$ \\
\hline Height $(\mathrm{cm})$ & $156 \pm 9,2$ & $160 \pm 6,1$ \\
\hline Weight $(\mathrm{kg})$ & $46,8 \pm 10,8$ & $78,8 \pm 12,3$ \\
\hline BMI $\left(\mathrm{kg} / \mathrm{m}^{2}\right)$ & $19,3 \pm 3,0$ & $30,8 \pm 4,7$ \\
\hline
\end{tabular}

Table 3. Personal data of adolescent females

Figure 6 shows the SAT-profiles of healthy (green area) and overweight (pink bars) female juveniles at the age of 13 years:

Healthy girls begin to develop a gynoid body silhouette with thicker fat layers at the extremities. The overweight girls have thicker adipose tissue layers at all measured body sites, including also at the extremities. The body sites at the trunk are significantly thicker than those of the healthy controls. The body fat distribution of those juveniles is comparable to 60-years-old females with type 2 diabetes and adult females with PCOS (Tafeit et al, 2000, Moeller et al, 2007). 


\section{SAT-Top of juveniles}

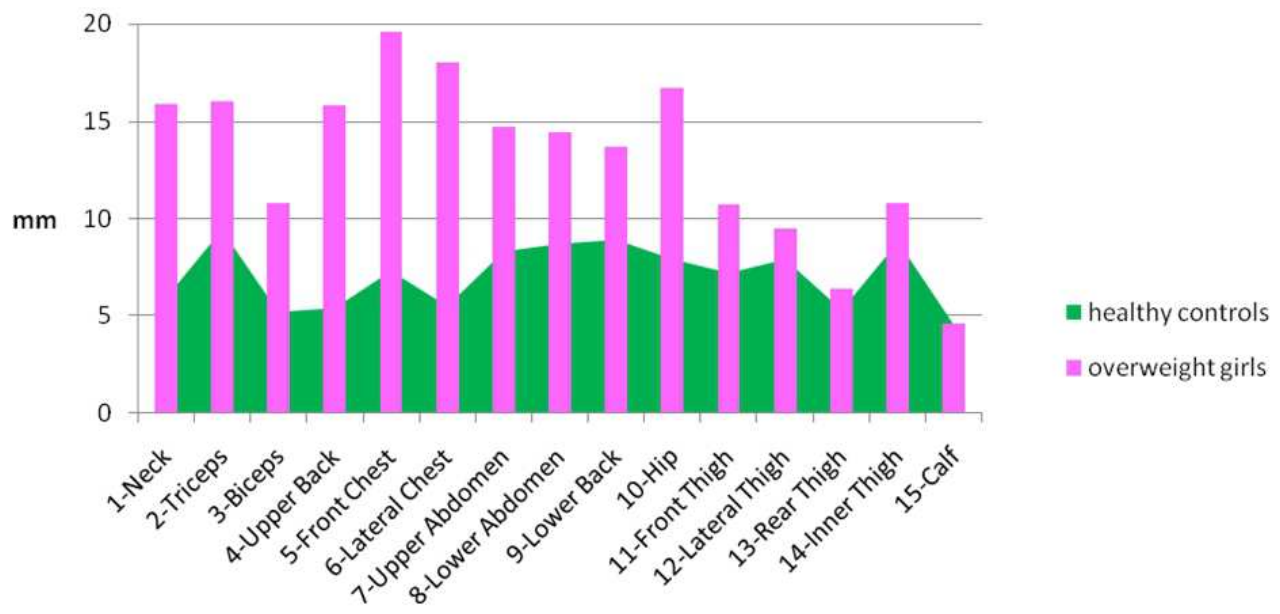

Fig. 6. SAT-Tops of healthy young girls (green area) and overweight girls (pink bars)

\subsection{Comparison of the three groups of patients}

The presented groups of patients (obese young females with PCOS, elderly females with type 2 diabetes and obese young girls) have an "apple"-like body fat distribution. Insulin resistance is suggested and consistently high risk for meatabolic diseases. The comparison of their SAT-Top plots is shown in figure 7:

\section{SAT-Top "Apple"-Type}

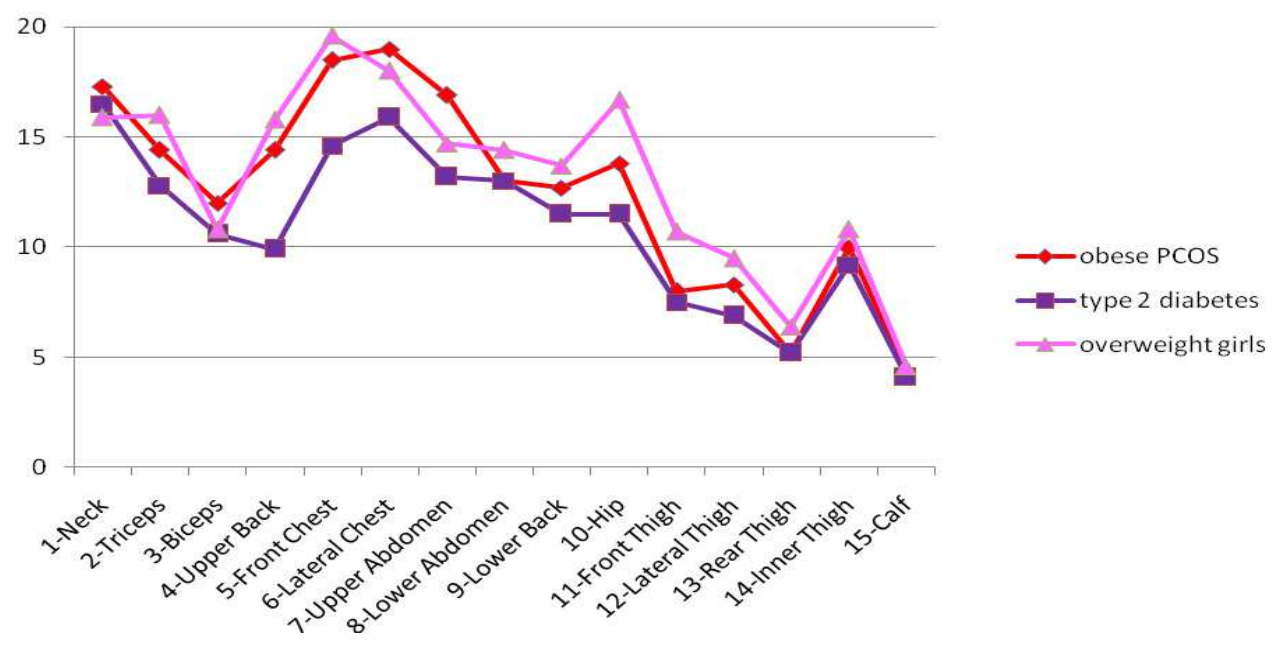

Fig. 7. SAT-Tops of obese females with PCOS (red line), females with type 2 diabetes (violet line) and overweight girls (pink line) 
The "apple"- like body fat distribution is nearly congruent in females at the age of 13 years (overweight girls), 27 years (females with PCOS) and 62 years (females with type 2 diabetes).

Factor analysis condenses the 15-dimensional information of SAT-Top data in a twodimensional diagram. Factor 1 , the $x$-axis, represents the combined measured data of the trunk, Factor 2, the y-axis, represents the data of the extremities. The blue line in the figure is the development healthy male controls from 9 (m09) to 80 years (m80). A 9 years old boy has thin fat layers at the trunk. To the age of 17 years the young male decreases the thickness of adipose tissue layers at the extremities. Between the age of 17 years to 40 years the young male increases fat layers on the trunk (m17, m22, m30, m40). Between 40 and 60 years male individuals turn back to thinner trunk layers (m40, m50, m60).

The red line shows the development of SAT-Top in females from 9 (f09) to 80 (f80) years. A 9 years-old girl has lean extremities and thin fat layers at the trunk. The thickness of adipose tissue layers at the extremities increases till the age of 22 (f22). Between 22 years and 60 years female persons increase their fat layers at their trunks and decrease it in older age between 60 and 80 years ( $\mathrm{f} 60-\mathrm{f} 80)$.

\section{FACTOR - PLOT}

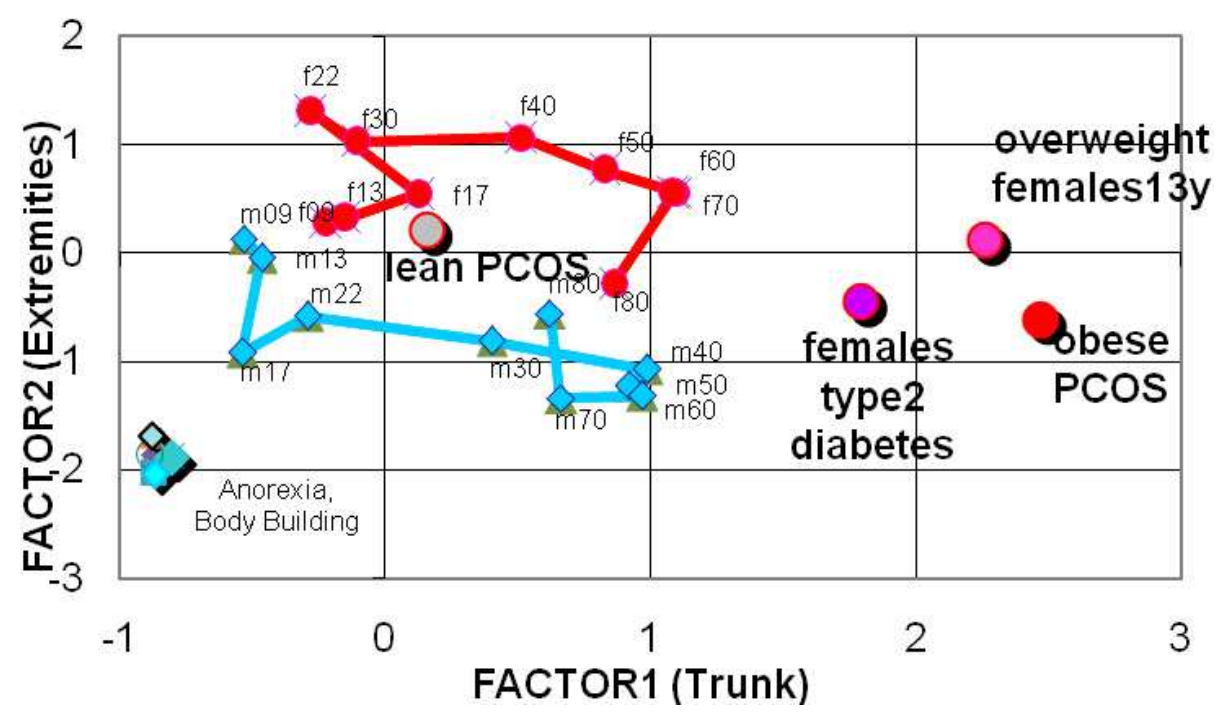

Fig. 8. Factor analysis condenses the SAT-Top information at the trunk and the body sites at the extremities into a two-dimensional plot, where the position of each subject can be shown.

The gynoid body silhouette seen in fertile young females is a signal reproductive potential. Regarding SAT-Top of females with PCOS, a high divergence of the typical femal body silhouette is evident. 
All SAT-Top plots shown in this chapter indicate, that almost all SAT layers of the upper body were significantly thicker in obese adolescents, obese females with PCOS and elderly females with type 2 diabetes, whereas SAT-layers at the legs were thinner compared to healthy controls of the same age group.

The patients described in this chapter, namely overweight females with PCOS, females with type 2 diabetes and overweight female adolescents are positioned at higher values of Factor 1 , indicating significantly thicker adipose tissue layers at the trunk. Factor 2, the condensed body sites at the extremities show lower values in females with PCOS and type 2 diabetes compared to the age matched control group.

\section{Conclusion}

PCOS is a common disorder, representing an early indication of future metabolic risks (Barber \& Franks, 2010, Sloboda et al, 2011). Obese females with PCOS have more severe clinical features than normal weight females with PCOS (lean PCOS) (Pandey \& Bhattacharya, 2010). Because of the world-wide epidemic increase of obesity the prevalence of PCOS appears to be rising, too. Overweight and obesity have a profound effect on the clinical manifestation of insulin resistance, PCOS, and type 2 diabetes. Females and adolescents with PCOS suffer also from psychicals burdens such as feeling less attractive than peers, they have less sexual contacts also because of obesity and hirsutism.

Insulin resistance is a condition of PCOS. Insulin resistance promotes fat storage because glucose is not taken by the cells. Increased levels of insulin in the blood stream cause wideranging consequences that can lead to a variety of other serious health conditions, such as coronary heart disease, hypertension, diabetes, as well as infertility, abnormal hair growth, cysts on the ovaries. These high insulin levels in the blood even in young girls are correlated to abdominal fat accumulation, which is highly difficult to demolish. Recent studies confirm that caloric intake and energy expenditure is at a comparable range in healthy and insulin resistant subjects. Therefore loosing weight and decreasing abdominal fat is a long-term and often frustrating process. Otherwise - it is highly important for females with PCOS and overweight adolescent girls to induce weight loss and fat loss in the abdominal area; more than in the general population (Hrzystek-Korpacka et al, 2011). Body weight loss is associated with beneficial effects on the clinical features. Insulin-sensitizing agents might support weight reduction programs (Grover \& Yialamas, 2011). The named patients (juvenile females, overweight young women with PCOS and elderly women with type 2 diabetes) should receive any support for weight loss (fat loss) by their practitioner. Especially the early intervention combating obesity in juveniles regarding growth and development stages must become the challenge of health services. Lifestyle modification is a key factor for enhancing quality of life for overweight and anovulatory females. Prior to ovulation induction treatments weight loss should be encouraged. The lower life quality is more attributed to obesity and hirsutism than to psychosocial status and social adjustment (Swallen et al, 2005). Any interventions in PCOS women that reduce trunk fat also influences hirsutism, acne, infertility and overall psychological and emotional condition (Elsenbruch et al, 2003). An individually adapted diet and physical activity should be the first steps in intervention strategies for overweight juveniles and women with PCOS. Early lifestyle interventions cause significantly reduced body fat and androgen levels, and improved insulin sensitivity and menstrual cycles (Norman et al, 2004). 
The process of an effective weight-loss management by diet and exercise can be monitored by SAT-Top measurement. The decrease of the thickness of adipose tissue layers might be a motivation factor for the patient to continue and maintain weight loss intervention programs.

\section{FACTOR - PLOT}

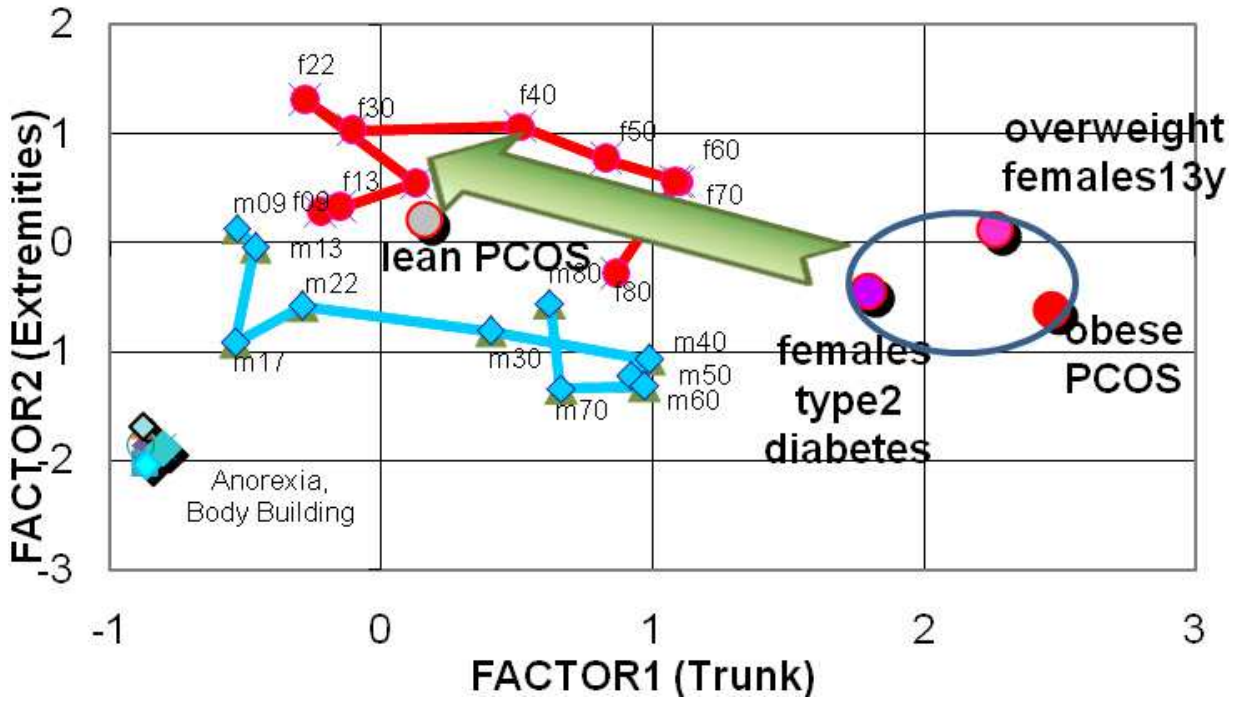

Fig. 9. Expectation of a successfull intervention program: the movement of an" apple"-like SAT-Top to a more "pear" - position in the factor plot (green arrow).

Furthermore, factor analysis of the SAT-Top data can immediately demonstrate, where the position of the patient in the factor plot is located. An effective trunk fat reduction program should move the position of the subject towards the area of healthy controls of the same age.

\section{References}

Asunción, M., Calvo, R., San Millán, J., Avila, S. \& Escobar - Morreale H. (2000). A prospective study of the prevalence of the polycystic ovary syndrome in unselected Caucasian women from Spain. Journal of Clinical Endocrinology \& Metabolism Vol. 85: pp 2434-2438.

Barber, T .\& Franks, S. (2010) Genetic basis of polycystic ovary syndrome. Expert Review of Endocrinology \& Metabolism Vol 5 (No.4): pp549-561.

Bronstein, J., Tawdekar, S., Liu, Y., Pawelczak, M., David, R. \& Shah, B. (2011). Age of onset of polycystic ovarian syndrome in girls may be earlier than previously thought. Journal of Pediatric \& Adolescent Gynecology Vol. 24 (No.1): pp 15-20.

Cupisti, S., Dittrich, R., Binder, H., Kajaia, N., Hoffmann, I., Maltaris, T. \& Beckmann, M. (2007). Influence of body mass index on measured and calculated androgen 
parameters in adult women with hirsutism and PCOS. Experimental and Clinical Endocrinology \& Diabetes Vol 115 ( No.6): pp 380-386.

Diamanti-Kandarakis, E., Kouli, C., Bergiele, A., Filandra, F., Tsianateli, T. \& Spina, G. (1999). A survey oft he polycystic ovary syndrome in the Greek island of Lesbos: hormonal and metabolic profile. Journal of Clinical Endocrinology \& Metabolism. Vol 84: pp 4006-4011.

Dunaif, A. (1997). Insulin resistance and the polycystic ovary syndrome: mechanisms and implications for pathogenesis. Endocrine Reviews . Vol 18: pp 774-800.

Elsenbruch, S., Hahn, S. \& Kowalsky, D. (2003) Quality of life, psychosocial well-being, and sexual satisfaction in women with polycystic ovary syndrome. Journal of Clinical Endocrinlogy \& Metabolism. Vol 88: pp 1551-1557.

Enea, C., Boisseau, N., Fargeas-Gluck, M., Diaz, V. \& Dugue B. (2011). Circulating androgens in women: exercise induced changes. Sports Medicine Vol 41 ( No.1): pp 1-15.

Goodarzi, M., Dumesic, D., Chazenbalk, G. \& Azziz, R. (2011). Polycystic Ovary Syndrome: etiology, pathogenesis and diagnosis. Nature Reviews Endocrinology Vol 7 ( No.4): pp 219-231.

Grover, A. \& Yialamas, M.(2011). Reproductive endocrinology: Metformin or thiazolidinedione therapy in PCOS? Nature Reviews Endocrinology Vol 7: pp128129.

Hatch, R., Rosenfield, R., Kim, H.\& Tredway D.(1981). Hirsutism: implications, etiology and management. American Journal of Obstetrics \& Gynecology Vol 114: pp 815-830.

Hrzystek-Korpacka, M., Malgorzata, P., Kustrzeba-Wojcicka, C., Gamian, A \& Noczynska A (2011). The effect of a one-year weight reduction program on seruyl uric acid in overweight - obese children and adolescents. Clinical Chemistry \& Laboratory Medicine Vol 49 : pp 915-921.

Moeller, R., Horejsi, R., Pilz, S., Lang, N., Sargsyan, K., Dimitrova, R., Tafeit, E., Giuliani, A., Almer, G \&, Mangge, H.(2007). Evaluation of risk profiles by subcutaneous adipose tissue topography in obese juveniles. Obesity Vol 15 (No.5): pp 1319-1324.

Moeller, R., Tafeit, E., Smolle, K., Pieber, T., Ipsiroglu, O., Duesse, M., Huemer, C., Sudi, K. \& Reibnegger, G.(2000a). Estimating percentage total body fat and determining subcutaneous adipose tissue distribution with a new noninvasive optical device Lipometer. American Journal of Human Biology Vol 12 ( No.2) pp 221-230.

Moeller, R.; Tafeit, E.; Sudi, K, \& Reibnegger , G. (2000) Quantifying the 'appleness' or 'pearness'of the human body by subcutaneous adipose tissue distribution. Annals of Human Biology , Vol .27 (No.1): pp 47-55.

Nathan, B. \& Moran, A. (2008). Metabolic complications of obesity in childhood and adolescence: more than just diabetes. Current Opinion in Endocrinology, Diabetes \& Obesity Vol.15 (No.1): pp 21-29.

Norman, R., Noakes, M., Wu, R., Davies, M., Moran, L.\& Wang, J. (2004) Improving reproductive performance in overweight/obese women with effective weight management. Human Reproduction Update Vol 10: pp 251-257. 
Oberfield, S., Sopher, A.\& Gerken A.(2011). Approach to the girl with early onset of pubic hair. Journal of Endcrinology \& Metabolism, Vol 96 ( No.6): pp 1610-1622.

Oliveira, A., Sampaio, B., Teixeira, A., Castro-Correia, C., Fontoura, M. \& Luis Medina, J. (2010). Polycystic ovary syndrome: challenge in adolescence. Endocrinologia y Nutricion Vol 57 ( No.7): pp 328-336.

Pandey, S. \& Bhattacharya. (2010) Impact of obesity on gynecology. Women's Health Vol 6 (No1): pp 107-117.

Sloboda, D., Hickey, M. \& Hart, R.(2011) Reproduction in females: the role of the early life environment. Human Reproduction Update Vol 17 (No.2): pp210-227.

Sudi, K., Tafeit, E., Moeller,R., Gallistl, S.\& Borkenstein, M.(2000). Relationship between different aubcutaneous adipose tissue layers, fat mass, and leptin in response to short-term energy restriction in obese girls. American Journal of Human Biology Vol 12 ( No.6): pp 803-813.

Swallen, K., Reither, E., Haas, S. \& Meier, A. (2005). Overweight, obesity and health-related quality of life among adolescents: the National Longitudinal Study of Adolescent Health. Pediatrics, Vol 115: pp 340-347.

Tafeit, E., Moeller ,R., Sudi, K.\& Reibnegger, G.(2000b). Artificial neural networks as a method to improve the precision of subcutaneous adipose tissue thickness measurement s by means oft he optical device Lipometer. Computers in Biology and Medicine Vol 30 (No. 6): pp 355-365.

Tafeit, E., Moeller R, Sudi, K., Horejsi, R., Berg, A.\& Reibnegger, G.(2001). Orthogonal factor coefficient development of subcutaneous adipose tissue topography (SAT-Top) in girls and boys. American Journal of Physical Anthropology Vol 115: pp 57-61.

Tafeit, E., Moeller, R., Giuliani, A., Urdl, W., Freytag, U., Crailsheim, K., Sudi, K \&, Horejsi, R. (2003). Subcutaneous adipose tissue pattern in lean and obese women with polycystic ovary syndrome. Experimental Biology and Medicine Vol 228: pp 710-716.

Tafeit, E., Moeller, R., Jurimae, T., Sudi, K.\& Wallner, S.(2007). Subcutaneous adipose tissue topography (SAT-Top) development in children and young adults. Collegium Anthropologicum Vol 31 (No. 2): pp 395-402.

Tafeit, E., Moeller, R., Pieber, T., Sudi, K.\& Reibnegger, G. (2000a). Differences of subcutaneous adipose tissue topography in type 2 diabetic women (NIDDM) and healthy controls. American Journal of Physical Anthropology Vol 113: pp 381-388.

Tafeit, E., Moeller, R., Sudi, K. \& Reibnegger, G. (2000). ROC and CART analysis of subcutaneous adipose tissue topography (SAT-Top) in type 2 diabetic women and healthy females. American Journal of Human Biology Vol 12 (No. 3): pp 388394.

Tafeit, E., Moeller, R., Sudi, K.\& Reibnegger, G. (1999). The determination of three subcutaneous adipose tissue compartments in non -insulin dependent diabetes mellitus women with artificial neural networks and factor analysis. Artificial Intelligence in Medicine Vol 17 (No. 2): pp 181-193.

The Rotterdam ESHRE-ASRM-Sponsored consensus workshop group. Revised consensous diagnostic criteria and long-term health risk related to polycystic ovary syndrome (PCOS)(2004). Human Reproduction Vol 19, pp 41-47. 
Zelzer, S., Fuchs, N., Almer, G.,Raggam, R.,Prueller, F., Truschnig-Wilders, M., Schnedl, W. Horejsi, R., Moeller, R.,Weghuber, D., Ille, R. \& Mangge, H. (2011) High density lipoprotein cholesterol level is a robust predictor of lipid peroxidation irrespective of gender, age, obesity, and inflammatory or metabolic biomarkers. Clinica Chimica Acta, in press. 


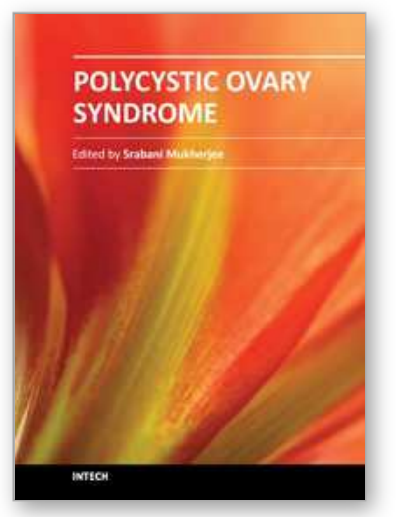

\author{
Polycystic Ovary Syndrome \\ Edited by Dr. Srabani Mukherjee
}

ISBN 978-953-51-0094-2

Hard cover, 168 pages

Publisher InTech

Published online 24, February, 2012

Published in print edition February, 2012

Brought into the limelight many decades ago, Polycystic Ovary Syndrome (PCOS) is still, to date, surrounded by controversy and mystery. Much attention has been attracted to various topics associated with PCOS research and there has been a healthy advance towards bettering the understanding of the many implications of this complex syndrome. A variety of topics have been dealt with by a panel of authors and compiled in this book. They span methods of diagnosis, reproductive anomalies, metabolic consequences, psychological mindset and ameliorative effects of various lifestyle and medical management options. These books are designed to update all associated professionals on the recent developments in this fast-growing field and to encourage further research into this thought-provoking subject.

\title{
How to reference
}

In order to correctly reference this scholarly work, feel free to copy and paste the following:

Moeller Reinhard, Giuliani Albrecht, Mangge Harald, Tafeit Erwin, Glaeser Margit, Schrabmair Walter and Horejsi Renate (2012). Android Subcutaneous Adipose Tissue Topography in Females with Polycystic Ovary Syndrome: A Visible Phenotype Even in Juveniles, Polycystic Ovary Syndrome, Dr. Srabani Mukherjee (Ed.), ISBN: 978-953-51-0094-2, InTech, Available from: http://www.intechopen.com/books/polycystic-ovarysyndrome/android-subcutaneous-adipose-tissue-topography-in-females-with-polycystic-ovary-syndrome-avisible-p

\section{INTECH}

open science | open minds

\section{InTech Europe}

University Campus STeP Ri

Slavka Krautzeka 83/A

51000 Rijeka, Croatia

Phone: +385 (51) 770447

Fax: +385 (51) 686166

www.intechopen.com

\section{InTech China}

Unit 405, Office Block, Hotel Equatorial Shanghai No.65, Yan An Road (West), Shanghai, 200040, China 中国上海市延安西路65号上海国际贵都大饭店办公楼405单元 Phone: +86-21-62489820

Fax: $+86-21-62489821$ 
(C) 2012 The Author(s). Licensee IntechOpen. This is an open access article distributed under the terms of the Creative Commons Attribution 3.0 License, which permits unrestricted use, distribution, and reproduction in any medium, provided the original work is properly cited. 